\title{
Detection of mRNAs for macrophage products in inflammatory bowel disease by in situ hybridisation
}

\author{
M Cappello, S Keshav, C Prince, D P Jewell, S Gordon
}

\begin{abstract}
In situ hybridisation has been used to detect mRNAs to the macrophage secretory products, lysozyme, interleukin $1 \beta$ and tumour necrosis factor- $\alpha$. Sections of paraformaldehyde fixed, frozen colonoscopic biopsies from patients with ulcerative colitis, Crohn's disease or normal controls were hybridised with specific radiolabelled probes and the signal detected by autoradiography. Lysozyme mRNA expression was more common in ulcerative colitis (22/27) and Crohn's disease (eight of eight) compared with controls (17/27). Positive cells were found mainly in the subepithelial region in normal colon, while in inflammatory bowel disease they also appeared in the deeper lamina propria. Immunocytochemistry in parallel sections showed that lysozyme mRNA was expressed only in macrophages or in metaplastic Paneth cells in longstanding inflammatory bowel disease. Tissue neutrophils did not express the lysozyme mRNA, though they have large stores of the protein. Tumour necrosis factor mRNA was detected in four of nine controls compared with $11 / 15$ inflammatory bowel disease patients. For interleukin $1 \beta$, three of eight controls were positive compared with 10 / 13 with ulcerative colitis. The tumour necrosis factor signal was located mainly in the deeper lamina propria whereas the interleukin $1 \beta$ was seen in subepithelial macrophages. These results confirm increased macrophage activation in inflammatory bowel disease and suggest functional heterogeneity within the intestinal macrophage population.

(Gut 1992; 33: 1214-1219)
\end{abstract}

A disturbance in immunoregulatory control has long been suspected to play a major role in the pathogenesis of inflammatory bowel disease. This belief is based on the observation of a variety of immune abnormalities, the response to immunosuppressive drugs and the pathology of the lesions.

Macrophages are crucial cells in the immune

Gastroenterology Unit, Radcliffe Infirmary, Oxford

M Cappello

C Prince

D P Jewell

Sir William Dunn School of Pathology, South Parks Road, Oxford

$S$ Keshav

$S$ Gordon

Correspondence to: Dr D P Jewell,

Gr DP Jewell,

Gadcliffe Infirmary, Oxford

Accepted for publication

6 January 1992 a number of cytokines, inflammatory mediators, tissue damaging enzymes, and free oxygen radicals. ${ }^{2}$

Previous studies have shown morphological and histochemical heterogeneity of human intestinal macrophages, ${ }^{4}$ with a distinct population being prominent in inflammatory bowel disease. Immunohistochemical studies ${ }^{5 ~}{ }^{\natural}$ using monoclonal antibodies have added further information as there is a peculiar pattern of expression of surface antigenic determinants which is not seen in normal colon, infectious colitis, or graftversus-host disease. This pattern consists of the presence of cells staining with the 3G8 and RFD9 antibodies. Functional studies have provided evidence of macrophage activation: isolated mononuclear cells from the colonic mucosa of inflammatory bowel disease patients seem to have enhanced antigen presenting activity, increased ability to undergo respiratory burst, ${ }^{8}$ ability to stimulate immunoglobulin scretion, ${ }^{9}$ and to release the specific secretory products, lysozyme and interleukin $1 \beta$." "I Using the polymerase chain reaction, increased levels of mRNA for interleukin 1 have recently been shown in homogenates of mucosal biopsies from patients with inflammatory bowel disease, although the results for tumour necrosis factor mRNA are discrepant. ${ }^{1213}$

Both functional studies on isolated cells and conventional mRNA analysis on tissue homogenates, however, might generate artefactual changes that arise from tissue handling, cell disaggregation and separation, or in vitro culture. In situ hybridisation offers a unique means to overcome most of these problems because it is able to detect mRNA sequences within cells and therefore allows precise localisation within histological preparations. ${ }^{1+}$

The aim of this study has been the use of in situ hybridisation to detect mRNAs for three specific macrophage products (lysozyme, interleukin $1 \beta$, tumour necrosis factor $\alpha$ ) in endoscopic biopsies of patients with ulcerative colitis or Crohn's disease.

Lysozyme is a major protein product of macrophages, and while it is produced constitutively in tissue culture, it is produced mainly by newly recruited or actively phagocytic cells in vivo. ${ }^{1 / 1}$ Thus, expression of lysozyme mRNA in vivo may be considered a marker for inflammatory rather than resident macrophages. ${ }^{17}$ Interleukin 1 and tumour necrosis factor, likewise, are induced by inflammatory stimuli, particularly bacterial lipopolysaccharide. The production of interleukin 1 and tumour necrosis factor is tightly regulated and increased concentrations of both cytokines can have deleterious effects, including circulatory failure and death. ${ }^{1 \times 19}$

To assess cytokine production in tissues, it is necessary to localise both protein and mRNA. Localisation of protein alone may identify not only producing cells, but also target cells and cells which have taken up the protein by endocytosis. ${ }^{17}$ On their own, mRNA levels may also be misleading, as some cytokines (particularly tumour necrosis factor), are regulated posttranscriptionally, with cellular stores of mRNA 
being maintained without translation into active protein. ${ }^{18}$ For lysozyme, cells containing mRNA actively synthesise lysozyme protein, while other cells (such as mature neutrophils) store preformed lysozyme protein in granules, without any mRNA being present.

\section{Methods}

\section{TISSUE SPECIMENS}

Colonoscopic biopsies were obtained from patients with active or inactive ulcerative colitis or Crohn's disease, diagnosed by classical clinical, radiological, endoscopic, and histological criteria. Patients with active disease were mostly being treated with oral corticosteroids and sulphasalazine, whereas those in remission were receiving sulphasalazine alone. Control colonic tissue was taken from patients undergoing colonscopy for diagnostic purposes, but who had a negative examination. Histologically normal duodenal tissue was used as positive control for the lysozyme probe, as lysozyme mRNA is strongly expressed in Paneth cells. Each biopsy was immediately fixed in 4\% paraformaldehyde in RNAse free phosphate buffered saline for $\mathbf{2 0}$ minutes at room temperature or at $4^{\circ} \mathrm{C}$ overnight. After fixation, each biopsy was divided into two halves. The first half was frozen in liquid nitrogen in OCT embedding medium. Cryostat sections, $5 \mu \mathrm{m}$ thick, were cut, mounted on poly-L-lysine coated microscope slides, air-dried, postfixed in $4 \%$ paraformaldehyde in phosphate buffered saline, rinsed, dehydrated through graded ethanol baths, and stored at $-20^{\circ} \mathrm{C}$ with desiccant, for up to three months. The second half was processed to paraffin wax and used for conventional immunocytochemistry.

\section{CYTOSPIN PREPARATIONS}

Monocytes from healthy volunteers were isolated by adherence to bacteriological petri dishes, after a Ficoll Paque (Pharmacia) sedimentation step, cultured in RPMI 1640 medium at $10 \% \mathrm{ml}$ concentration for at least four hours and then stimulated with lipopolysaccharide (Sigma) $10 \mu \mathrm{g} / \mathrm{ml}$. Viability, as determined by Trypan blue exclusion, always exceeded $90 \%$. Fluorescence activated cell sorter analysis of cell suspensions showed that 90 (5)\% were monocytes. After two, four, and 18 hours incubation, cells were harvested and cytospin preparations onto poly-L-lysine coated slides were made. Slides were subsequently processed as for tissue sections.

\section{MOLECULAR PROBES}

A 640 base pair long BamHl-Rsal restriction fragment of the lysozyme cDNA was subcloned in both directions into the Hinc II site of the pGEM3 expression vector plasmid (Promega). ${ }^{15}$ Two forms of recombinant plasmids were generated, depending on the orientation of the insert DNA with respect to the phage T7 and SP6 promoters. ${ }^{35}$ S-labelled riboprobes of high specific activity were prepared by $\mathrm{T} 7$ polymerase action on Hind III linearised plasmids, giving sense-strand (negative control) and antisense strand (complementary probe) riboprobes.

Single stranded 30 base long oligonucleotide probes for tumour necrosis factor $\alpha$ and interleukin $1 \beta$ were supplied by British Biotechnology (Oxford, UK). Probe cocktails, consisting of an equimolar mixture of exon specific probes (exons 3, 4A, and $4 \mathrm{~B}$ for tumour necrosis factor- $\alpha$, exons 5,6 , and 7 for interleukin $\beta$ ) were used. ${ }^{32} \mathrm{P}-5^{\prime}$ end labelling was obtained using the T4 polynucleotide kinase reaction, with a specific activity of $2-3 \times 10^{8} \mu \mathrm{g}$. An irrelevant 36-base long oligonucleotide probe, purchased from Dupont (Randomer NEP 550) was used as a negative control.

Probe size and labelling was checked by electrophoresis in urea polyacrylamide denaturing gels. ${ }^{20}$

\section{IN SITU HYBRIDISATION}

\section{Riboprobes}

In situ hybridisation with the lysozyme RNA probes was carried out with minor modifications of a standard protocol. ${ }^{1+}$ Special care was used to avoid RNAse contamination (baked glassware, solutions made up in water treated with diethylpyrocarbonate). Briefly, slides were rehydrated in water, treated with $0.2 \mathrm{M} \mathrm{HCl}$ for 20 minutes at room temperature, rinsed with $10 \mathrm{mM}$ TRIS, $1 \mathrm{mM}$ EDTA buffer, then treated with $20 \mu \mathrm{g} / \mathrm{ml}$ proteinase $\mathrm{K}$ in TRIS/EDTA buffer for 10 minutes. Digestion was stopped by incubating the slides with $0 \cdot 2 \%$ glycine in water for 30 seconds. Slides were subsequently postfixed in $4 \%$ paraformaldehyde in phosphate buffered saline for 20 minutes at room temperature, acetylated in $0.25 \%$ acetic anhydride in $0.1 \mathrm{M}$ ( $\mathrm{pH} \mathrm{8)}$ triethanolamine solution for 10 minutes, washed three times in phosphate buffered saline, then dehydrated and air dried for at least one hour.

The hybridisation mixture containing $10^{5}$ $\mathrm{cpm} / \mu \mathrm{l}$ of ${ }^{35} \mathrm{~S}$-labelled RNA probe was pipetted onto dry slides and covered with siliconised glass coverslips. The hybridisation mixture consisted of $50 \%$ formamide, $10 \%$ dextran sulphate, $0.01 \%$ polyvinylpyrrolidone, $1 \mu \mathrm{g} / \mu \mathrm{l}$ tRNA, $10 \mathrm{mM}$ TRIS pH 7.4, $1 \mathrm{mM}$ EDTA, $1 \mathrm{mM}$ pyrophosphate, $10 \mathrm{mM}$ dithiothreitol. Hybridisation was carried out for 18 hours at $50^{\circ} \mathrm{C}$ in a humid environment.

After hybridisation, coverslips were removed by incubating the slides in a solution of $50 \%$ formamide, $0.01 \% \mathrm{BSA}, 0.01 \%$ Ficoll, $0.01 \%$ polyvinlypyrrolidone, $10 \mathrm{mM}$ TRIS $\mathrm{pH} 7 \cdot 4$, $1 \mathrm{mM}$ EDTA, $1 \mathrm{mM}$ pyrophosphate, and $10 \mathrm{mM}$ dithiothreitol at $50^{\circ} \mathrm{C}$ for one hour. The slides were washed in $0.5 \mathrm{M} \mathrm{NaCl}, 10 \mathrm{mM}$ TRIS pH $7 \cdot 4,1 \mathrm{mM}$ EDTA for 15 minutes, then digested with RNAse A at $20 \mu \mathrm{g} / \mathrm{ml}$ in the same buffer for 30 minutes at $37^{\circ} \mathrm{C}$. The slides were rinsed once with the same buffer, then transferred to $2 \times$ SSC $(20 \times \mathrm{SSC}=3 \mathrm{M} \mathrm{NaCl} ; 0.3 \mathrm{M}$ trisodium citrate) at $45^{\circ} \mathrm{C}$ for one hour, followed by $0.1 \times$ SSC at $60^{\circ} \mathrm{C}$ for another hour. The slides were dehydrated through graded ethanol baths with $0.3 \mathrm{M}$ $\mathrm{NH}_{4}$-Acetate, air dried and processed for autoradiography. 
Patient characteristics for studies using probes to lysozyme, interleukin 1 and tumour necrosis factor

\begin{tabular}{|c|c|c|c|c|c|}
\hline & Controls & & $\begin{array}{l}\text { Ulcerati } \\
\text { colitis }\end{array}$ & & $\begin{array}{l}\text { Crohn's } \\
\text { disease }\end{array}$ \\
\hline \multicolumn{6}{|l|}{ Lysozyme } \\
\hline & 27 & & 27 & & 8 \\
\hline Males & 15 & & 12 & & 5 \\
\hline Mean age (yr) & $49 \cdot 6$ & & $49 \cdot 8$ & & $36 \cdot 1$ \\
\hline Range & $23-70$ & & $21-79$ & & $21-57$ \\
\hline Active & & & 14 & & 6 \\
\hline Remission & & & 13 & & 2 \\
\hline & & L-sided & 15 & Ileo-colic & 3 \\
\hline & & Total & 12 & Colonic & 5 \\
\hline \multicolumn{6}{|l|}{ Interleukin 1} \\
\hline & 8 & & 13 & & \\
\hline Males & 5 & & 6 & & \\
\hline Mean age (yr) & $53 \cdot 2$ & & $45 \cdot 2$ & & \\
\hline Range & $14-75$ & & $21-69$ & & \\
\hline \multicolumn{6}{|l|}{ Active } \\
\hline L-sided & & & 4 & & \\
\hline Total & & & 9 & & \\
\hline \multicolumn{6}{|c|}{ Tumour necrosis factor } \\
\hline $\mathrm{n}$ & 9 & & 12 & & 3 \\
\hline Males & 6 & & 6 & & 1 \\
\hline Mean age (yr) & 58 & & $53 \cdot 1$ & & $34 \cdot 7$ \\
\hline Range & $14-90$ & & $30-69$ & & $17-57$ \\
\hline \multirow[t]{3}{*}{ Active } & & & 7 & & 3 \\
\hline & & L-sided & 7 & Colonic & 3 \\
\hline & & Total & 5 & & \\
\hline
\end{tabular}

\section{Oligonucleotide probes}

Probes were resuspended at $10^{5} \mathrm{cpm} / \mu \mathrm{l}$ in a hybridisation mixture containing $0.8 \mathrm{M} \mathrm{NaCl}$, $30 \%$ formamide, $10 \%$ dextran sulphate, $0.4 \mu \mathrm{g} /$ ml tRNA, $0.02 \%$ BSA, polyvinylpyrrolidone, Ficoll, 0.01\% pyrophosphate, $5 \mathrm{mM}$ EDTA, 50 $\mathrm{mM}$ TRIS. Hybridisation was performed at $37^{\circ} \mathrm{C}$ overnight. Posthybridisation washes were carried out in $4 \times \mathrm{SSC}$ at $37^{\circ} \mathrm{C}$ for one hour and $45^{\circ} \mathrm{C}$ for another hour.

\section{Autoradiography}

Dried hybridised slides were dipped in Ilford $\mathrm{K} 5$ prewarmed $\left(43^{\circ} \mathrm{C}\right)$ liquid emulsion and exposed in the dark at $4^{\circ} \mathrm{C}$ for four days (RNA probes) or nine days (oligonucleotide probes). They were developed in Kodak D19 developer at $17^{\circ} \mathrm{C}$, counterstained with haematoxylin and eosin and mounted under coverslips in $\operatorname{DePeX}(\mathrm{BDH})$.

\section{Immunocytochemistry}

Immunocytochemistry was carried out on paraffin embedded tissue sections, using the following antibodies: (a) a rabbit antihuman lysozyme antiserum (DAKO) and (b) a mouse antihuman monoclonal antibody KPl (kindly provided by Dr D Y Mason), detecting a formalin resistant epitope of the CD68 cluster, a highly glycosylated intracellular protein expressed by most tissue macrophages. This antibody can be used on paraffin embedded tissue. ${ }^{21}$

The PAP technique was used on tissue sections stained with the antilysozyme antiserum. Endogenous peroxidase was blocked with hydrogen peroxide in Tris buffered saline (pH 7-4). Preparations were incubated with the primary antibody for 60 minutes, rinsed in Tris buffered saline and then incubated with the secondary antibody (mouse anti rabbit, diluted in Tris buffered saline/normal human serum) for 30 minutes. After further washing, they were finally incubated with the PAP complex (horse radish peroxidase anti-peroxidase) for 30 minutes. Peroxidase activity was developed with diaminobenzidine and hydrogen peroxide. Preparations were counterstained with Harris' haematoxylin, dehydrated and mounted in DPX.

A three stage immunoperoxidase technique was used in specimens stained with the KP1 antibody. Briefly, after blocking of endogenous peroxidase activity, sections were first incubated with the primary antibody, rinsed, incubated with a peroxidase- conjugated rabbit anti-mouse antibody (diluted in Tris buffered saline/normal human serum), rinsed and incubated with a peroxidase conjugated swine anti rabbit antibody. Developing and mounting were per-
Figure 1: Section of healthy colonic mucosa, $>5 \mathrm{~cm}$ from a carcinoma showing lysozyme $m R N A$ in cells situated just below the epithelial basement membrane (arrows).

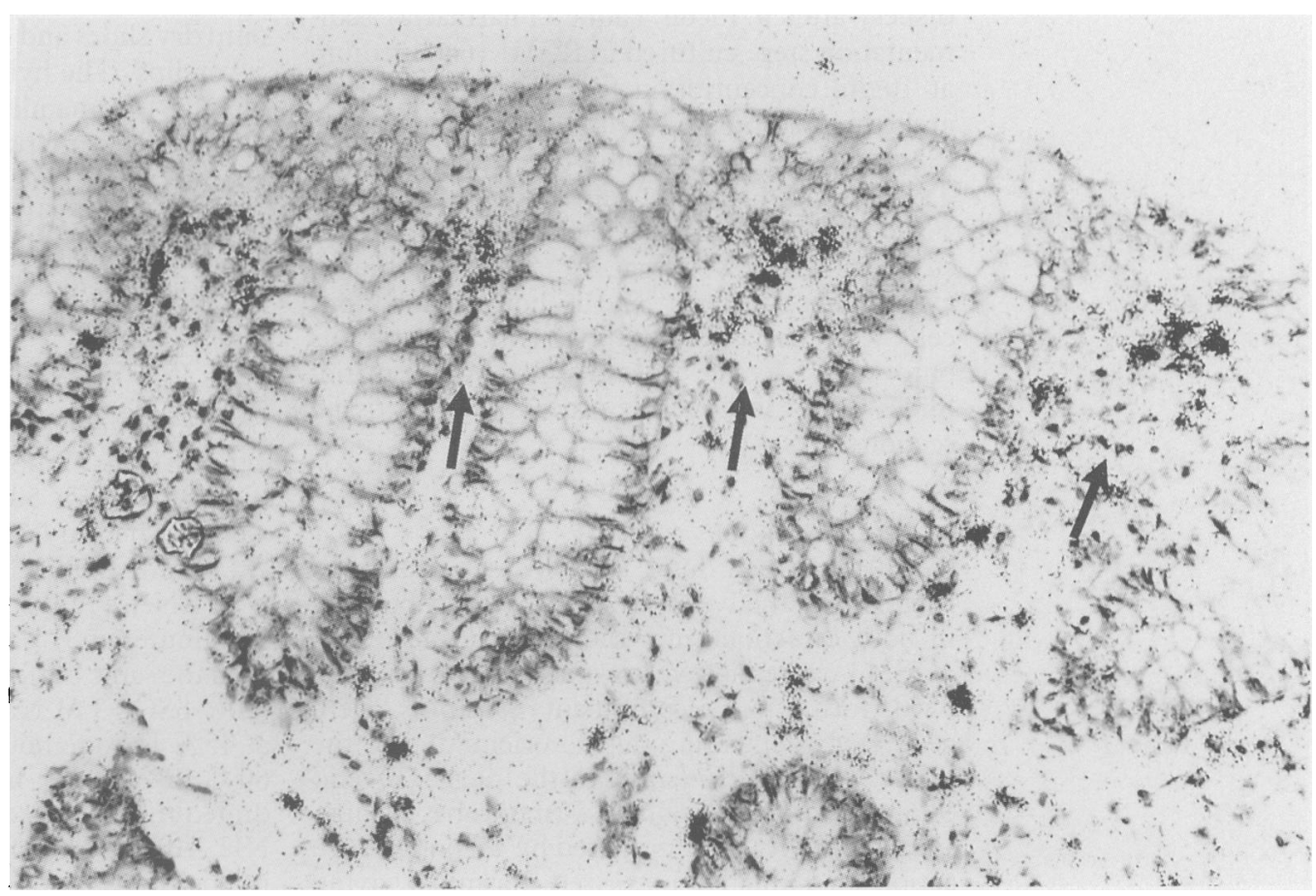




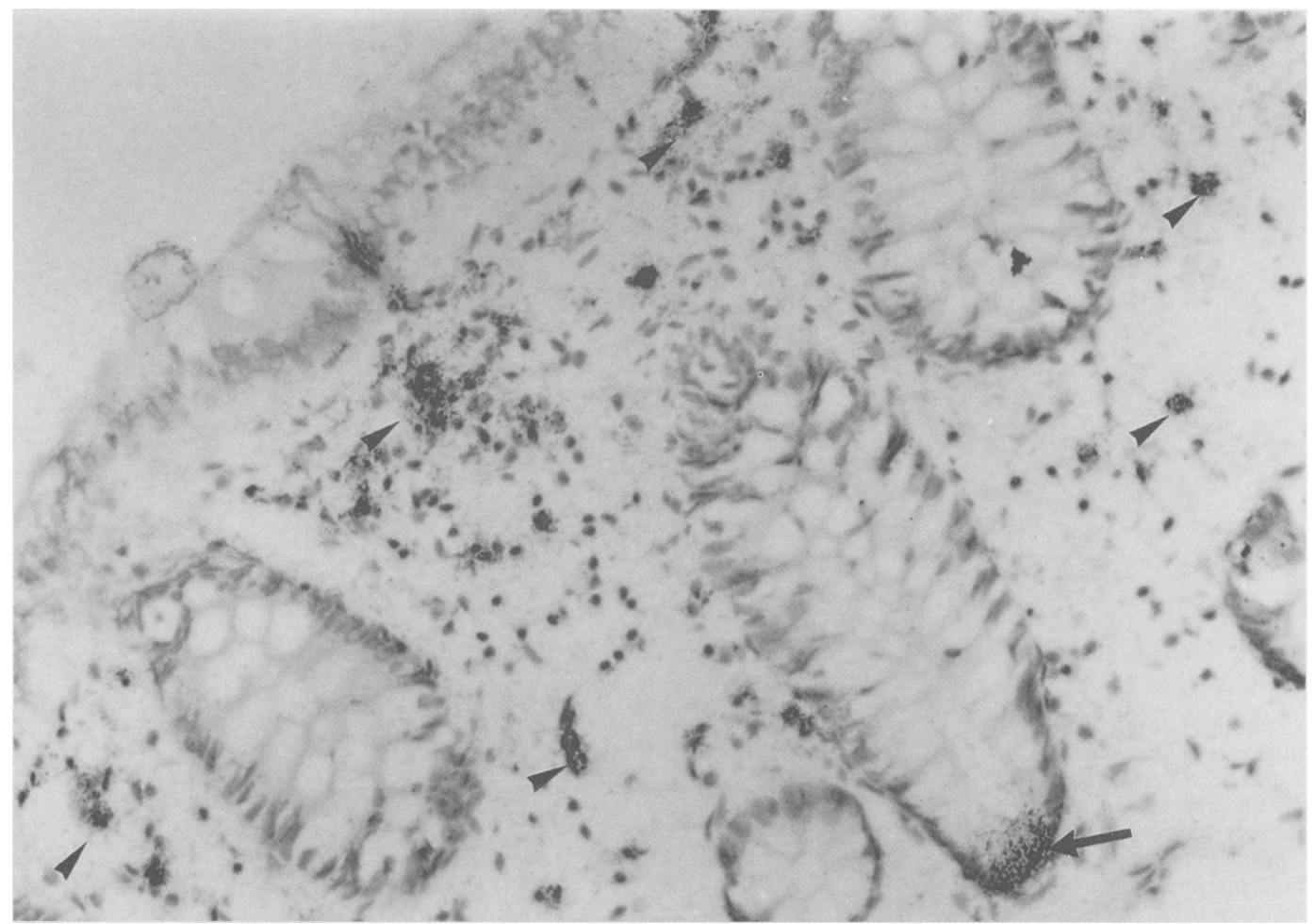

Figure 2: Lysozyme mRNA in ulcerative colitis. Positive cells lie below the basement membrane as well as in the deeper lamina propria (arrowheads). Metaplastic Paneth cells are also expressing the mRNA (arrow).

formed according to the same protocol as for the PAP procedure.

\section{STATISTICAL ANALYSIS}

Statistical analysis was performed using $\chi^{2}$ analysis with a Yates' correction for small numbers or by Fisher's exact test.

\section{Results}

The Table gives the demographic features of the patients studied. For technical reasons it was not always possible to obtain good results for the three probes on tissue from the same patient. Thus, results are presented independently for each probe.

\section{LYSOZYME MRNA EXPRESSION}

Lysozyme mRNA was investigated in 27 control subjects with histologically normal colonic tissue, in 27 patients with ulcerative colitis (14 active, 13 quiescent) and eight patients with Crohn's disease (six active, two quiescent).

In normal colonic specimens lysozyme mRNA expression was found in cells lying beneath the surface epithelium in $17 / 27$ cases $(63 \%$ ) (Fig 1). In the remaining 10 control patients, there were occasional positive cells scattered throughout the lamina propria.

In ulcerative colitis lysozyme mRNA positive cells were more common than in controls as expression was found in $22 / 27(81 \%)$ specimens, though the difference was not statistically significant (with Yates correction: $p=0.075$, Fisher's exact test, $p=0 \cdot 07$ ). Lysozyme mRNA expression was not related to histological disease activity, as there was no significant difference between active and inactive ulcerative colitis (lysozyme positive cells in 12 of 14 active ulcerative colitis, 10 of 13 inactive ulcerative colitis).

Lysozyme mRNA positive cells were detected in all sections from the eight patients with Crohn's disease.

In either ulcerative colitis or Crohn's disease, compared with normal colon, lysozyme positive cells were found not only beneath the epithelium, but also in the deeper lamina propria: positive cells in the deeper lamina propria were observed only in $30 \%$ of normal colonic specimens compared to $100 \%$ in inflammatory bowel disease (Fisher exact test, $\mathrm{p}<0 \cdot 01$ ). Figure 2 illustrates lysozyme mRNA in a colonic biopsy specimen from a patient with longstanding ulcerative colitis.

The signal intensity, evaluated by grain count, was stronger in inflammatory bowel disease, although the difference was again not significant (data not shown).

\section{CONTROLS}

All the colonic sections hybridised to the lysozyme sense probe were negative. Normal duodenal sections provided an excellent positive control, as lysozyme mRNA was strongly expressed in Paneth cells and Brunner's glands. Occasionally positive cells in the villus tips, compatible with small bowel macrophages, were detected. The demonstration of lysozyme positive macrophages in the small bowel was achieved by increasing the exposure time to six to seven days whereas positive colonic macrophages could be detected at three to four days.

In all sections the increase in exposure time was associated with a stronger autoradiographic signal but, at the same time, with a higher 
Figure 3: IL-I mRNA in ulcerative colitis showing scattered cells throughout the lamina propria which are strongly positive (arrows). The intestinal lumen is indicated by $L$, and a crypt lumen on the left by $C$.

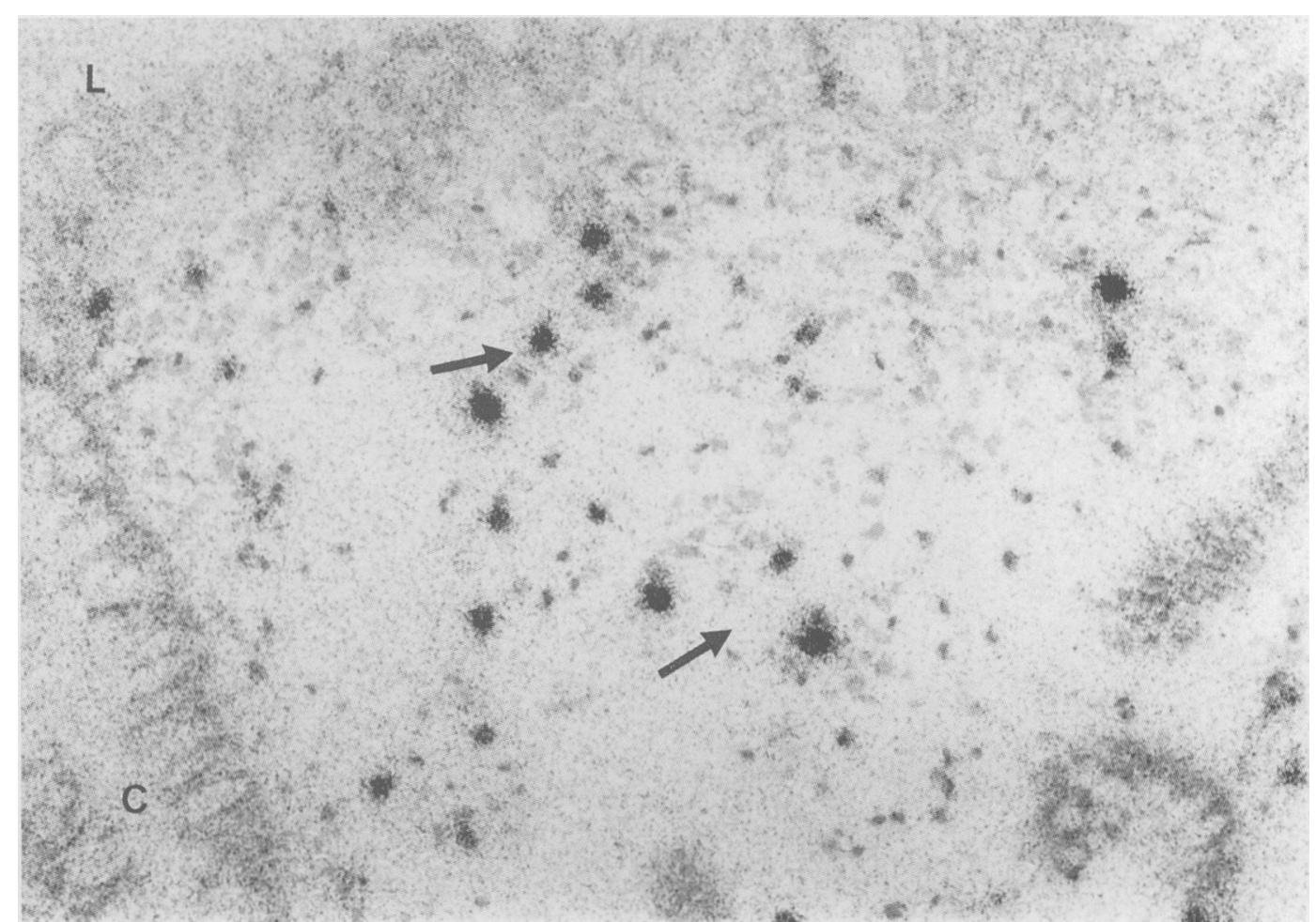

background staining. In colonic sections the optimal signal-to-noise ratio was achieved at three to four days.

\section{IMMUNOCYTOCHEMISTRY}

In colonic sections lysozyme mRNA expression was found in lamina propria macrophages and, in five patients with longstanding inflammatory bowel disease, in metaplastic paneth cells. Neutrophils did not express the lysozyme signal, though they are known to have large stores of the protein. To confirm this observation, the phenotype of lysozyme mRNA positive cells was studied by conventional immunocytochemistry in parallel sections. Expression of the lysozyme protein was found in both polymorphonuclear leucocytes and in lamina propria cells with macrophage morphology. Lysozyme mRNA, however, was found only in cells staining with the monoclonal antibody KP1, recognising most tissue macrophages.

TUMOUR NECROSIS FACTOR AND INTERLEUKIN $\beta$ MRNA EXPRESSION

Tumour necrosis factor mRNA was expressed in four of nine controls compared with 11/15 inflammatory bowel disease (nine of 12 ulcerative colitis; two of three Crohn's). For interleukin $1 \beta$ mRNA, three of eight controls were positive, compared with $10 / 13$ ulcerative colitis patients (Fig 3). Positive cells were recognised as lamina propria macrophages, as they expressed the pan macrophage marker CD68, as observed in parallel sections stained with the monoclonal antibody KP1. Tumour necrosis factor positive cells were located mainly in the deeper lamina propria, whereas the interleukin 1 signal was diffuse, but predominant in subepithelial macrophages. Epithelial cells showed no expression of tumour necrosis factor or interleukin $1 \mathrm{mRNA}$.
CONTROLS

To confirm the specificity of the probes, peripheral blood monocytes were also studied before and after incubation with LPS. Only very few cells in preparations from unstimulated monocytes expressed tumour necrosis factor or interleukin $1 \mathrm{mRNA}$, while the number of positive cells and the signal intensity increased significantly in preparations of cells stimulated with LPS. Maximal tumour necrosis factor mRNA expression was observed after two hours incubation with LPS, with subsequent decline, whereas interleukin $1 \mathrm{mRNA}$ signal increased during prolonged incubation with maximal expression at 18 hours.

All the sections and cytocentrifuge preparations of peripheral blood monocytes hybridised to the irrelevant oligonucleotide probe (Randomer NEP 550) were negative. The best signal-to-noise ratio, for both tissue sections and cytopsin preparations, was achieved at nine days exposure. Background staining was always higher using ${ }^{32} \mathrm{P}$-labelled oligonucleotide probes, however, compared with ${ }^{35} \mathrm{~S}$-labelled riboprobes.

\section{Discussion}

Conventional histology, histochemistry, and immunohistochemistry have revealed that the phenotype of tissue macrophages is extremely heterogenous, being influenced also by changes in the microenvironment. ${ }^{22}$ In vitro studies have also shown the complexity of their secretory repertoire with the identification of a large number of active substances involved in antimicrobial defence, inflammation, immunity, wound healing and tissue modelling. ${ }^{23}$ These findings suggest that macrophage biosynthetic activity is tightly regulated and that distinct subgroups of macrophages may be characterised by their functional secretory profile. 
Inflammatory conditions of the gut (whether a result of infection, experimental manipulations or idiopathic) are associated with increased turnover and activation of intestinal macrophages, which represent a large fraction of the total macrophage pool of the body. Previous observations have suggested that in ulcerative colitis or Crohn's disease macrophage activation is associated with increased heterogeneity and the appearance of specialised subpopulations of cells. ${ }^{+13}$ Studies on isolated mononuclear cells from the colonic mucosa can be misleading, however, because of the lack of a reliable and efficient technique to purify intestinal macrophages without altering their function.

Using in situ hybridisation, this study has shown that lysozyme mRNA expression may be increased in patients with inflammatory bowel disease compared to controls, as detection of the mRNA was achieved in about $85 \%$ of the sections versus $63 \%$, although this difference was not statistically significant. Furthermore, in inflamed tissue, cells expressing the lysozyme gene were observed not only in the superficial lamina propria, where resident colonic macrophages are usually found, but also in the deeper lamina propria. These results might have two different interpretations: (i) the recruitment of new populations of cells from the blood stream: or (ii) the activation in situ of certain subsets of tissue macrophages, which do not express the gene constitutively. Studies using in situ hybridisation in murine tissues have shown marked heterogeneity in lysozyme mRNA expression in resident tissue macrophages and in experimental infections with bovine gamma globulin and Plasmodium yoelli. ${ }^{16}$ The presence of $\mathrm{mRNA}$ for lysozyme in normal colon is compatible with previous suggestions that colonic macrophages are normally activated as a result of the transepithelial passage of bacterial products. ${ }^{2}$

Little information is currently available on the role of interleukin 1 and tumour necrosis factor in inflammatory bowel disease..$^{12} 13$ The present results show that there may be enhanced expression of tumour necrosis factor $\alpha$ and interleukin $1 \beta$ mRNAs in ulcerative colitis, and tumour necrosis factor $\alpha$ mRNA in Crohn's disease, compared with controls. Interestingly, the pattern of localisation of the two mRNAs is different, because the tumour necrosis factor signal is found mainly in the deeper lamina propria and the interleukin 1 signal mainly beneath the epithelium. This study cannot conclude with certainty the nature of the cells expressing mRNA for interleukin 1 or tumour necrosis factor, although the majority are probably macrophages. Thus, these data show functional heterogeneity within the intestinal macrophage population, with the appearance of at least two subsets of cells with a different secretory repertoire. Mahida et al, ${ }^{6}$ using conventional immunohistochemistry, identified unique subsets of macrophages in inflammatory bowel disease, staining with the monoclonal antibodies RFD9 and 3G8. 3G8 positive cells were distributed throughout the inflamed lamina propria but RFD9 positive cells appeared deeper in the lamina propria. Double labelling studies will be required to show definitely that tumour necrosis factor mRNA and RFD9 antigen are expressed by the same cells.

In conclusion, the use of specific molecular probes and in situ hybridisation allows a functional analysis of tissue macrophages. Phenotypic studies have previously shown intestinal macrophages to be a heterogeneous population and the present data show functional heterogeneity in inflamed tissue. These studies will be extended to investigate the expression of mRNA for other immunoregulatory cytokines.

We wish to thank Miss Lindsey Jefferies for her expert secretarial assistance and Mrs Caroline Prince for her technical support. M. Cappello was in receipt of a grant form the Italian Ministry of Education.

1 MacDermott RP, Stenson WF. The immunology of idiopathic inflammatory bowel disease. In: Kirsner JB, Shorter RG Diseases of the colon, rectum and anal canal. Baltimore, USA Williams \& Wilkins, 1988: 295-314.

2 Hume DA, Doe WF. Role of macrophages in cellular defense. In: Heyworth MF, Jones AL. Immunology of the gastrointestinal tract and the liver. New York: Raven Press Ltd, 1988: $23-45$.

3 Keshav S, Gordon S. Macrophage function in the gastrointestinal tract. In: Peters $\mathrm{T}$, ed. Inflammation in the gastrointestinal tract. Hull: Corners Publications, 1990.

4 Selby WS, Poulter LW, Hobbs S, Jewell DP, Janossy G. Heterogeneity of HLA-DR positive histiocytes in human intestinal lamina propria: a combined histochemical and intestinal lamina propria: a combined histochemical and immuno

5 Allison MC, Cornwall S, Poulter LW, Dhillon AP, Pounder RE. Macrophage heterogeneity in normal colonic mucosa and in inflammatory bowel disease. Gut 1988; 29: 1531-8.

6 Mahida YR, Patel S, Gionchetti P, Vaux D, Jewell DP. Macrophage subpopulations in lamina propria of normal and inflamed colon and terminal ileum. Gut 1989; 30: 826-34.

7 Mahida YR, Wu KC, Jewell DP. Characterization of antigenpresenting activity of intestinal mononuclear cells isolated from normal and inflammatory bowel disease, colon and from normal and inflammatory bo

8 Mahida YR, Wu KC, Jewell DP. Respiratory burst activity of intestinal macrophages in normal and inflammatory bowel intestinal macrophages in normal

9 Wu KC, Mahida YR, Priddle JD, Jewell DP. Effect of human intestinal macrophages on immunoglobulin production by human intestinal mononuclear cells isolated from patients with inflammatory bowel disease. Clin Exp Immunol 1990 79: $35-40$.

10 Mee AS, Jewell DP. Monocytes in inflammatory bowe disease. Clin Sci 1980; 58: 295 .

11 Mahida YR, Wu KC, Jewell DP. Enhanced production of interleukin- $1 \beta$ by mononuclear cells isolated from mucosa with active ulcerative colitis or Crohn's disease. Gut 1989; with active $835-8$.

12 Stevens C, Walz G, Zanker B, Singaram C, Lipman M, Strom TB. Interleukin-6 (IL-6), interleukin-1 $\beta$ (IL-1 $\beta$ ) and tumo necrosis factor-alpha (TNF-alpha) expression in inflamnecrosis factor-alpha (TNF-alpha) expression in in
matory bowel disease. Gastroenterology 1990; 97: A475.

13 Isaacs K, Sartor RB, Wang A, Haskill JS. Protiles of cytokine activation in inflammatory bowel disease tissue: measurement by cDNA amplification. Gastroenterology 1990; 97 A455.

14 Hofler H. Principles of in situ hybridization. In: Polak JM, McGee JO'D. In situ hybridization. Principles and practice. Oxford: Oxford University Press, 1990: 15-29.

15 Chung LP, Keshav S, Gordon S. Cloning the human lysozyme cDNA: inverted ALU repeat in the mRNA and in situ hybridization for macrophages and paneth cells. Proc Natl Acad Sci 1988; 85: 6227-31.

16 Keshav S, Chung LP, Milon G, Gordon S. Lysozyme is an inducible marker of macrophage activation in murine tissues as demonstrated by in situ hybridization. $\mathcal{F}$ Exp Med 1991 174: 1049-58.

17 Mason DY, Taylor CR. The distribution of muramidase (lysozyme) in human tissues. $\mathcal{F}$ Clin Pathol 1975; 28: 124-32.

18 Beutler B, Cerami A. The biology of cachectin/TNF-alpha: primary mediator of the host response. Ann Rev Immunol 1989; 7: 625-55.

19 Dinarello C. Interleukin-1. Dig Dis Sci 1988; 33: 25-35S

20 Maniatis T, Fritsch EF, Sambrook J. Molecular cloning: laboratory manual. Cold Spring Harbor, New York: Cold Spring Harbor Laboratory, 1988: 188-96.

21 Pulford KAF, Rigney EM, Micklem KJ, Jones M, Stross WP Garler KC, et al. KPl: a new monoclonal antibody that Garler $\mathrm{KC}$, et al. KMl. a new moch monocyte/macrophage associated antigen in routinely

22 Gordon S, Keshav S, Chung LP. Mononuclear phagocytes: tissue distribution and functional heterogeneity. Curr Opin Immunol 1988; 1: 26-35.

23 Nathan CF. Secretory products of macrophages. 7 Clin Invest 1987; 79: 319-26. 